\title{
OPTIMISING THE YIELD OF ENERGY FROM BIOMASS BY ANALYTICAL MODELS OF THE RATE OF GROWTH
}

\author{
J. Abolins ${ }^{1 *}$, J. Gravitis ${ }^{2}$, J. Kosmacha ${ }^{3}$ \\ ${ }^{1}$ Institute of Atomic Physics and Spectroscopy, University of Latvia, \\ 4 Skunu Str., Rīga, LV-1586, LATVIA \\ ${ }^{2}$ Latvian State Institute of Wood Chemistry, \\ 27 Dzerbenes Str., Rīga, LV-1006, LATVIA \\ ${ }^{3}$ Faculty of Physics and Mathematics, University of Latvia, \\ 8 Zellu Str., Rīga, LV-1002, LATVIA \\ *e-mail: jclover@latnet.lv
}

\begin{abstract}
In the reported study of growth-rates of grey alder (Alnus incana) stands at different quality sites the authors, as a continuation of an earlier study, propose and use analytical models to approximate experimental data of mean annual increments of standing stock. The model equations of growth-rate functions are further used to optimise the cutting age by minimising the total area of stands for sustainable annual supply of biomass. The growth-rate behaviour with the age of natural grey alder stands is described by an exponential function of three parameters defining the initial and the maximum growth-rates, and the age at which the growth-rate maximum is reached. None of the parameters is known from experiment, and they are found by least-square fit of the available experimental mean values appraised at the chosen time intervals into the model. A high correlation between the experimental data and the model function is found. The optimum cutting age of 18 years determined in the earlier study is confirmed. In farmed stands the growth-rate is made to continue increasing at a lower speed, and is well approximated by a linear function, in which case it is shown that the cutting age cannot be optimised with respect to the area minimum existing under the condition of a decreasing growth-rate after passing a maximum. In the case of a constant or slowly growing annual increment the authors suggest considering the ratio between the increment of stock per unit of the total area to the increase in the area. The overall efficiency of using the product of photosynthesis for a 20 -year-old grey alder stand is roughly estimated to be $0.3 \%$.
\end{abstract}

\section{INTRODUCTION}

Regardless of the recent shock and continuing quakes of the global financial system that attracted attention to the top-priority measures for reviving the economic activity, the problems of energy safety have not disappeared or been forgotten and are still urgent. Neglecting the risks for environment and people, new oil-wells are being projected and drilled in places most vulnerable ecologically to access the last drops for the sake of reducing the energy dependence while staying addicted to prodigious use of the limited resource.

The energy of solar radiation accumulated by photosynthesis in biomass is considered as a reliable and renewable alternative to the limited fossil carriers and as a solution of the problem of energy dependence. However, since the energy flow 
that the planet receives from the Sun is not (and cannot be) infinite, neither is this resource unlimited, although in a different way. While the limited stock of fossil resources is available, the flow of the resource depends on the ability of humans to extract and consume it. The biomass and the energy from biomass are limited by the flow of energy the planet receives from a practically unlimited cosmic source. Apart from that, sustainable flow of biomass is limited by other factors such as the temperature at which photosynthesis can proceed and availability of water, soil, and land - to harvest enough biomass to satisfy the need for it a big enough surface area is required to catch the necessary amount of photons to produce and accumulate new biomass. Only the plant biomass, at least so far, accumulates the solar energy producing new biomass.

In the earlier study [1] a graphical method was considered that allows evaluation of the most appropriate felling age of grey alder grown for sustainable supply of biomass and energy from biomass. In the present study, some analytical models describing the experimentally observed growth-rates of grey alder stands $[2,3]$ are offered and used to optimise the grey alder cutting age with respect to the land use for sustainable supply of wood biomass.

\section{THE MODELS AND THE METHOD}

The general pattern of the growth-rate of natural growths of perennial species is described well enough by a rather simple exponential function:

$$
y(t)=(b+t) \cdot e^{-\frac{t}{a}},
$$

where $t$ is the time, $b$ and $a$ are constants determining the initial rate of growth at $t$ $=0$.

The time at which the growth-rate reaches its maximum is:

$t_{m}=a-b$.

In Eq. (1) the growth-rate (the annual increment of the stock of biomass) is assumed to be proportional to the age (time $t$ ) with the coefficient equal to one and is subject to the exponential decrease with age.

By substitution:

$$
x=\frac{t}{a-b},
$$

the dimensionless (relative) time normalised with respect to the time of maximum growth-rate can be introduced, while the growth-rate function (1) can be normalised with respect to its maximum value by the factor equal to the reciprocal of the maximum value reached at $t=t_{m}$ :

$$
y(x)=\frac{a-b}{a} e^{\frac{a-b}{a}}\left(\frac{b}{a-b}+x\right) e^{-\frac{a-b}{a} x} .
$$

Defining new constants: 


$$
\alpha \equiv \frac{a-b}{a} \text { and } \beta \equiv \frac{b}{a-b}
$$

Equation (4) representing the normalised growth-rate function of the dimensionless variable $x$ can be rewritten in the form:

$$
y(x)=\alpha \cdot e^{\alpha}(\beta+x) \cdot e^{-\alpha x}
$$

resembling Eq. (1) and the general time dependence of the mean annual increment of stock observed experimentally [2]. A general pattern of function (6) is presented in Fig. $1 b$.
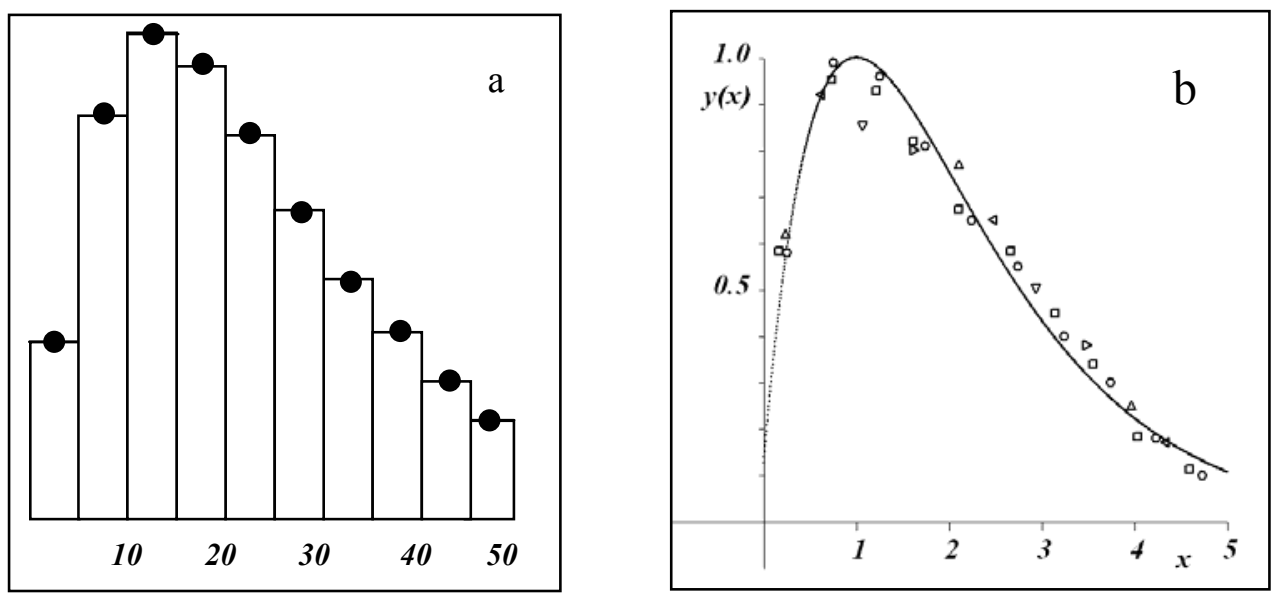

Fig. 1. (a) dynamics of the 5-year mean growth-rate of stock in natural alder stands [2] represented in the diagram of arbitrary scale; $(b)$ general outline of the analytical model of growth-rate function (Eq. (6)); plots of experimental data [2] normalised by the best mean square fits refer to the stands of different site quality: $\bigcirc-$ I, $\square-$ II, $\Delta-$ III .

The experimental data [2] are available as the mean annual increments of stock during 5-year periods for grey alder growths up to the age of 50 years at the sites of different quality class. The model of the growth-rate function is constructed under the assumption that the mean annual increment calculated from the increase in stock over 5 years corresponds to the actual growth-rate in the middle of a respective 5-year period. Since neither the initial and maximum growth-rates nor the age of maximum growth-rate are known experimentally, these are chosen as adjustable parameters to be found by the best fit between the experimental data and the analytical model. The best fit is selected by satisfying the least-square and correlation criteria. Most essential of the three adjustable parameters is the age at which the maximum growth-rate is reached, since it is used to calculate the optimum cutting age with respect to the minimum area of land necessary for sustainable annual supply of biomass [1].

The stand area necessary to cut for satisfying the current annual demand for biomass is proportional to the reciprocal of stock $S\left(x_{o}\right)$ at cutting age $x_{o}$. The stock as a function of $x_{o}$ can be expressed through the integral of growth-rate function (6): 


$$
S\left(x_{o}\right)=\int_{0}^{x_{o}} y(x) d x=\mathrm{const}\left[1-\left(1+\frac{\alpha}{\alpha \beta+1} x_{o}\right) \cdot e^{-\alpha x_{o}}\right] .
$$

The dependence of the total area $A\left(x_{o}\right)$ under stand of the selected species on cutting age $x_{o}$ is described by function $f\left(x_{o}\right)$ derived from the expression:

$$
A\left(x_{o}\right)=\frac{x_{o}}{S\left(x_{o}\right)}=\text { const } \frac{x_{o}}{1-\left(1+\frac{\alpha}{\alpha \beta+1}\right) e^{-\alpha x_{o}}}=\text { const } \cdot f\left(x_{o}\right) .
$$

With account for (5), function $f\left(x_{o}\right)$ can be presented in terms of growth-rate parameters $(a, b)$ :

$$
f\left(x_{o}\right)=\text { const } \cdot \frac{x_{o}}{1-\left(1+\frac{a-b}{a+b} x_{o}\right) \cdot e^{-\alpha x_{o}}} .
$$

The optimal cutting age is found from the $x_{o}$ value at which function $f\left(x_{o}\right)$ has its minimum. The analytical expression of the minimum condition is rather complicated, so the minimum of $f\left(x_{o}\right)$ is found much easier by plotting function (9).

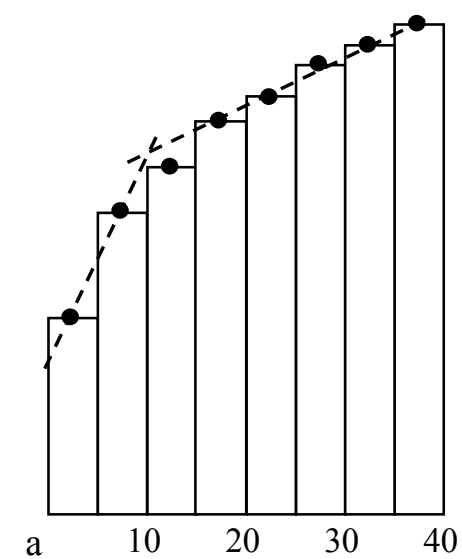

Fig. 2. Dynamics of growth-rate of farmed grey alder stands [3]. Dotted lines illustrate linear growth-rate approximations.

The growth-rate function has a different pattern in cultivated forest areas. As seen from the data obtained at experimental sites [3], appropriate thinning of the stand allows keeping growth-rates constant or even slightly increasing after reaching the point where the increase in the annual increment - the mean of the slope $d y / d x$ - drops to a smaller value (Fig. 2) and the growth-rate $y(x)$ may be approximated by a linear function:

$$
y(x)=c+k \cdot x,
$$

the stock being presented as 


$$
S\left(x_{o}\right)=S+\int_{1}^{x_{o}} y(x) d x=S+\frac{x_{o}-1}{2}\left[2 c+k\left(x_{o}+1\right)\right],
$$

where $S$ is the stock at $x=1-$ the age at which the annual increment accepted as the growth-rate unity (growth-rate at the point at which the mean slope of $y(x)$ drops) is reached. The unit of stock may be accepted as the amount of biomass accumulated at unity growth-rate by unity of age under which measure $S$ is equal to 0.5 (the mean between 0 at $x=0$ and 1 at $x=1$ ).

Constant $k$ describes the rate at which the annual increment in biomass changes after reaching point $x=1$, while constant $c$ is chosen from considerations that growth-rate function $y(x)=1$ at $x=1$ :

$$
c=1-k \text {. }
$$

Under these conditions, function $f\left(x_{o}\right)$ defined by Eq. (8) for the optimum cutting age is presented as

$$
f\left(x_{o}\right)=\text { const } \cdot \frac{x_{o}}{1+\left(x_{o}-1\right) \cdot\left[2 c+k\left(x_{o}+1\right)\right]}
$$

or, with account for Eq. (12), as

$$
f\left(x_{o}\right)=\text { const } \cdot \frac{x_{o}}{k x_{o}^{2}+(1-k)\left(2 x_{o}-1\right)},
$$

wherefrom the minimum of the total stand area is found under the condition:

$$
x_{o}=\sqrt{-\frac{1-k}{k}},
$$

suggesting that function $A\left(x_{o}\right)$ has a real minimum only if the growth-rate passes a maximum, that is - under circumstances of a negative slope $k<0$.

\section{RESULTS AND DISCUSSION}

If the rate of decrease in the annual increment at $x \geq 1$ is twice slower $(k=-0.5)$ than the average increase $(k=1)$ within $0 \leq x \leq 1$, the optimum cutting age according to $(15)$ is $\sqrt{3}$, i.e. close to 18 years.

In the case the growth-rate $y(x)$ after a definite age either continues increasing slower or stays constant, some different criteria for optimisation should be selected. One of the options might be a reasonable ratio of the increase in stock (biomass) per unit of the total area $\Delta S(x) / A(x)$ to the increase in the total area $\Delta A(x)$. Practically, this ratio is less than 0.5 , meaning that the total area increases more than twice against the increase in the long-term yield per unit area (Table 1). However, to assess the real yield in this case one should take into account the amount of biomass harvested by thinning the stand to keep an increasing annual increment in the stock. These data presently are not available, and a separate study would be required to consider the efficiency of maintenance to sustain increasing annual increments of alder stocks beyond 20 years of the growth age. For 
comparison, in Table 2 the experimental data $[2,3]$ are presented for the stocks of 20 -year old alder stands and sustainable long-term biomass yields from different quality sites.

Dynamics of current stock [3] and long-term sustainable supply of biomass from grey alder stands of site quality $\mathrm{H}_{20}=16$

\begin{tabular}{|c|c|c|c|c|c|}
\hline \multirow{2}{*}{$\begin{array}{l}\text { Age, } \\
\text { years }\end{array}$} & \multicolumn{3}{|c|}{ Stock, $\mathrm{m}^{3} / \mathrm{ha}$} & \multirow{2}{*}{$\begin{array}{l}\text { Long-term } \\
\text { stock, } \%\end{array}$} & \multirow{2}{*}{$\begin{array}{c}\text { Total area, } \\
\%\end{array}$} \\
\hline & current & long-term & $\begin{array}{c}\text { current } \\
\text { increment }\end{array}$ & & \\
\hline 15 & 129 & 8.60 & & 91 & 75 \\
\hline 20 & 189 & 9.45 & 60 & 100 & 100 \\
\hline 25 & 253 & 10.12 & 64 & 107 & 125 \\
\hline 30 & 322 & 10.73 & 69 & 114 & 150 \\
\hline 35 & 394 & 11.24 & 72 & 119 & 175 \\
\hline 40 & 469 & 11.72 & 75 & 124 & 200 \\
\hline
\end{tabular}

As seen from Tables 1 and 2, farming activities may provide considerably higher current yields from old growths - nearly 2.5 times greater at the age of 40 years compared with 20 , sustainable long-term yields being merely $24 \%$ higher (without the account for biomass extracted by thinning), while the total area increases twice. Yields from natural growths at highest quality sites successfully compete with farmed alder plantations (Table 2).

Stock and energy content of 20-year old alder stands at the sites of different quality

\begin{tabular}{|c|c|c|c|c|c|c|c|}
\hline \multirow{3}{*}{ Site quality } & \multicolumn{2}{|c|}{ Stock, $\mathrm{m}^{3} \mathrm{ha}^{-1}$} & \multicolumn{4}{|c|}{ Energy content*, TJ $\cdot \mathrm{ha}^{-1}$} & \multirow{3}{*}{ Ref. } \\
\hline & \multirow[b]{2}{*}{ current } & \multirow[b]{2}{*}{ long-term } & \multicolumn{2}{|c|}{ absolutely dry } & \multicolumn{2}{|c|}{ air-dry } & \\
\hline & & & current & long-term & current & $\begin{array}{l}\text { long- } \\
\text { term }\end{array}$ & \\
\hline I & 226 & 11.30 & 2.132 & 0.10660 & 1.780 & 0.089 & \multirow{3}{*}[2]{} \\
\hline II & 178 & 8.90 & 1.6793 & 0.08396 & 1.402 & 0.070 & \\
\hline III & 130 & 6.50 & 1.2264 & 0.06132 & 1.024 & 0.051 & \\
\hline $\mathrm{H}_{20}=20$ & 264 & 13.20 & 2.4906 & 0.12453 & 2.079 & 0.104 & \multirow{3}{*}{ [3] } \\
\hline $\mathrm{H}_{20}=16$ & 189 & 9.45 & 1.7830 & 0.08915 & 1.488 & 0.074 & \\
\hline $\mathrm{H}_{20}=12$ & 111 & 5.55 & 1.0472 & 0.05236 & 0.874 & 0.044 & \\
\hline
\end{tabular}

*The energy content is calculated under the assumption that air-dry wood has moisture of $12 \%$ and density of $525 \mathrm{~kg} \mathrm{~m}^{-3}$ [4]; hence at the amount of absolutely dry wood biomass of $462 \mathrm{~kg}$ in $1 \mathrm{~m}^{3}$, the heat content of absolutely dry wood is $20.42 \mathrm{MJ} \mathrm{kg}^{-1}$ [4] and of air-dry wood - $15 \mathrm{MJ} \mathrm{kg}^{-1}$ [5].

Considering the use of biomass as a source of primary energy, it is of interest to compare different options by the efficiency of photosynthesis. Assuming the average annual insolation during the vegetation period to be $1000 \mathrm{kWh} / \mathrm{m}^{2}$ at the latitudes of Latvia [6], the total insolation per ha over a period of 18 years is 
$18 \cdot 10^{4} \mathrm{MWh}$. Taking the stock of an 18-year old natural alder growth equal to $204 \mathrm{~m}^{3} / \mathrm{ha}[1,2]$ and the absolutely dry content of alder wood equal to $462 \mathrm{~kg} / \mathrm{m}^{3}$ [4], the total amount of absolutely dry alder wood is $94248 \mathrm{~kg} / \mathrm{ha}$. The heat content of absolutely dry alder wood being $20.42 \mathrm{MJ} / \mathrm{kg}$ [4], the energy density is $1.9245 \mathrm{TJ} / \mathrm{ha}$ (or about $535 \mathrm{MWh} / \mathrm{ha}$ ); hence, the total efficiency of photosynthesis by such alder growth is around $0.3 \%$. At least the same amount of energy in the form of electricity can be obtained during 18 years from $130 \mathrm{~m}^{2}$ of photovoltaic panels working at $20 \%$ efficiency, that is - from a 77 times smaller area. Producing such amount of electricity by burning wood chips at a thermal power plant (of 35$40 \%$ efficiency) would require a 2.5 to 3 times larger area under alder plantations, suggesting that compared with photovoltaic transformation growing wood for electricity production is an extremely inefficient way of converting solar energy. It should be noticed, however, that the calculated $0.3 \%$ efficiency is an underestimate because of neglecting the underground biomass; besides, the leaves and branches are not accounted for in the amount of stock cubic metres related to the volume of timber only. For comparison, the energy content of rapeseed oil yield from 18 ha is $20.358 \mathrm{MWh}$ [1], the efficiency of photosynthesis (without account for the energy derived from straw) being $\sim 0.011 \%$ - about 30 times lower.

\section{CONCLUSIONS}

For sustainable annual supply of biomass a definite land area is permanently needed to grow the selected species. The total area for growing perennial species depending on the rotation period is a function of the cutting age, for which reason fast-growing species are obviously preferable to minimise the necessary total land area unless there are specific requirements for the quality of biomass.

Presented analytical models (6) and (10) are in good agreement with the available growth-rate data of grey alder (Alnus incana) stands up to the age of 50 years. They show that the minimum of the necessary plantation area can be used as a criterion for optimisation of biomass yields only in the cases when the growthrate function passes a maximum.

The growing of biomass as a source of primary energy for electricity generation is inefficient - both in terms of the land and the solar radiation use at the present state-of-art of thermoelectric transformation technologies. This can be recommended as a source of $\mathrm{CO}_{2}$-neutral fuel for local heating.

Assessment of the efficiency of farming efforts and utilisation of forest waste wood biomass requires a separate study of data from the forestry sector.

\section{REFERENCES}

1. Gravitis, J., \& Abolins, J. (2010). Sustainable supply of energy from biomass. Latv. J. Phys. Tec. Sci., 47 (1), 57-63.

2. Daugavietis, M. (2006). Rate of grey alder growth. Grey Alder in Latvia, Silava, 90-96 (in Latvian).

3. Daugavietis, M., Bisenieks, J., \& Daugaviete, M. (2009). The interconnections of valuation characteristics of grey alder stands. Substantiation of Deciduous Trees Cultivation and Rational Utilisation, New Products and Technologies, Latvian State Institute of Wood Chemistry, 14-17 (in Latvian). 
4. Daugavietis, M. (2006). Utilisation of grey alder wood. Grey Alder in Latvia, Silava, 107-114 (in Latvian).

5. Smil, V. (1999). Energies. Cambridge (MA): MIT Press, 210.

6. http://www.innovation.lv/fei/

\title{
ANALĪTISKU MODEḶU IZMANTOŠANA ENERĢĒTISKĀS KOKSNES ROTĀCIJAS CIKLA OPTIMIZĒĔSANAI
}

\author{
J. Āboliņš , J. Grāvītis, J. Kosmača \\ Kopsavilkums
}

Darbā aplūkotas analītiskas izteiksmes ilgstoši nepārtrauktai enerğijas un/vai biomasas apgādei nepieciešamās kopējās dažāda vecuma mežaudžu platības optimizēšanai. Krājas pieaguma dinamikas modelēšanai izmantotā eksponenciālā funkcija un pēc kopējās plantācijas platības minimuma kritērija aprēķinātais optimālais ciršanas vecums (18 gadi) labi korelē ar datiem par baltalkšņa savvaļas audžu augšanas gaitu [2] un no tiem izrietošo ikgadēji iegūstamās biomasas un primārās enerǵijas daudzumu no plantācijas kopējās platības laukuma vienības (attiecīgi $11,33 \mathrm{~m}^{3} /$ ha un $89,25 \mathrm{GJ} / \mathrm{ha}$ ). Pieñemot vidējo gada insolāciju Latvijas apstākḷıs $1000 \mathrm{kWh}, 18$-gadīgai baltalkšņa audzei pret kopējo saules starojuma spektru aprēķinātā fotosintēzes vidējā efektivitāte sastāda $0,3 \%$, kas liecina par to, ka pie esošajām termoelektriskās enerǵijas transformācijas tehnoloğiskajām iespējām biomasas izmantošana elektroenerğijas ǵenerēšanai nevar konkurēt ar fotoelektriskajiem starojuma enerǵijas pārveidotājiem ne no saules enerǵijas, ne zemes izmantošanas efektivitātes viedokḷa. To var rekomendēt kā $\mathrm{CO}_{2}$ neitrālu kurināmo decentralizētai siltuma apgādei un vidējas jaudas katlu mājām.

29.07.2010. 